\title{
PENGEMBANGAN VIDEO TUTORIAL PADA MATA KULIAH PENGANTAR STATISTIKA PENDIDIKAN UNTUK PEMBELAJARAN E-LEARNING
}

\author{
Oleh: Raharjo*
}

\begin{abstract}
This study aims to produce a product video tutorials on introductory statistics course of education for e-learning in Civics Program S1 UNJ FIS. The method used is the method of Development and Research $(R \& D)$. The study produced a video tutorial and a website for e-learning in introductory statistics courses of education with the name of the website http://statistikapendidikan.com. The study found that in this way the quality of teaching and learning outcomes can be improved with either. From the results of the feasibility test/quality video tutorials for e-learning through the website http://statistikapendidikan.com obtained the average number of 3.89 with good category.
\end{abstract}

Key Words: Video tutorials, e-learning, learning, web, internet.

\section{PENDAHULUAN}

\section{A. Latar Belakang Masalah}

Kemajuan teknologi informasi dewasa ini melahirkan berbagai macam aplikasi yang memungkinkan untuk dapat dimanfaatkan dalam penyelenggaraan pendidikan berbasis teknologi informasi (IT-Based Education). Salah satunya adalah kemajuan dalam bidang internet menjadikan batas ruang dan waktu semakin menipis. Teknologi internet dan aplikasi yang berjalan di atasnya ini memungkinkan untuk dimanfaatkan dalam proses pendidikan, terutama sebagai sarana pembawa konten pendidikan (educational delivery medium). Salah satu bidang yang tersentuh dampak perkembangan teknologi ini adalah dunia pendidikan. Sebagai sebuah sumber informasi yang hampir tanpa batas, jaringan internet memenuhi kapasitas untuk dijadikan sebagai salah satu sumber pembelajaran dalam dunia pendidikan. Bahkan, beberapa sekolah atau perguruan tinggi mencanangkan lahirnya sistem pembelajaran yang berbasiskan teknologi jaringan, seperti dengan lahirnya konsep tentang distance learning, webbased education, dan e-learning.

Perkembangan pesat di bidang teknologi khususnya teknologi informasi dan komunikasi telah membawa perubahan yang signifikan dalam berbagai bidang, termasuk pula dalam dunia pendidikan. Salah satu aplikasi yang dapat digunakan adalah aplikasi Camtasia Studio, aplikasi ini dapat membantu dan melatih seorang

*Dosen Program Studi Pendidikan Pancasila dan Kewarganegaraan Jurusan Ilmu Sosial Politik, Fakultas Ilmu Sosial Universitas Negeri Jakarta 
guru/dosen dalam menyampaikan serta berinteraksi dengan audiens atau mahasiswanya, Camtasia Studio memiliki kemampuan untuk merekam sesuatu yang ada dalam layar, termasuk kegiatan di desktop, presentasi Powerpoint, narasi suara, dan webcam studio. Dengan menggunakan Camtasia Studio seorang guru dapat menyajikan video tutorial perkuliahannya baik dalam bentuk halaman web, CD-ROOM, maupun peralatan portable lainnya. Dengan ketersediaan video tutorial tentunya dapat membantu seorang dosen dan mahasiswa khususnya dalam mempelajari materi sebuah perkuliahan yang kadang membutuhkan langkahlangkah yang cukup rumit atau sulit, seperti pada mata kuliah pengantar statistika pendidikan yang merupakan salah satu mata kuliah wajib bagi mahasiswa S1 PPKN FIS UNJ. Seorang mahasiswa dapat memutar kembali langkah-langkah atau pembelajaran statistika pendidikan yang dianggap sulit atau rumit tersebut kapanpun dan dimanapun, tanpa harus meminta seorang dosen mengulang-ulang materi yang sudah disampaikannya.

Teknologi Informasi lainnya yang juga dapat menunjang proses pembelajaran di sekolah adalah teknologi yang berbasis internet (e-learning). E-Learning merupakan aplikasi pembelajaran di sekolah/perguruan tinggi berbasis online dan digital, di dalamnya mencakup administrasi pembelajaran, materi pembelajaran dan adanya interaksi langsung antara mahasiswa/siswa dan guru/dosen [Romi Satria Wahono, 2007]. Melihat perkembangan fenomena ini, tentu akan sangat tertinggal jika kita tidak bisa memanfaatkan teknologi informasi, khususnya untuk bidang pendidikan. Berdasarkan pertimbangan tersebut di atas, maka kami merasa tergerak ikut bertanggung jawab dalam upaya mengejar ketertinggalan masyarakat kita dalam memanfaatkan teknologi informasi ini, khususnya pembuatan sebuah video tutorial pengantar statistika pendidikan untuk pembelajaran berbasis e-learning pada mata kuliah pengantar statistika pendidikan yang dianggap sulit oleh sebagian mahasiswa.

Mata kuliah Statistika oleh sebagian mahasiswa dianggap sebagai mata kuliah yang cukup sulit, karena mata kuliah tersebut banyak terkait dengan perhitungan angka-angka atau rumus-rumus yang aplikasinya harus dipelajari melalui langkah-langkah perhitungan yang cukup rumit khususnya bagi mahasiswa yang berbasis ilmu-ilmu sosial. Sehingga seorang dosen tidak jarang harus mengulang-ulang materi perkuliahannya karena sebagian mahasiswa belum cukup jelas terhadap materi yang disampaikan hanya dengan sekali di kelas. 
Melalui video tutorial maka
diharapkan mata kuliah Pengantar

Statistika Pendidikan yang oleh sebagian mahasiswa sebagai mata kuliah yang sulit dapat diatasi, dosen tidak perlu mengulang-ulang materi kuliahnya di depan kelas, karena dengan video tutorial langkah-langkah pengerjakan statistika yang cenderung rumit dapat dipelajari oleh mahasiswa secara berulang-ulang melalui video tutorial yang disediakan dimanapun dan kapanpun karena video tutorial tersebut juga terhubung kedalam jaringan internet, hal ini karena video tutorial yang sudah dikembangkan tersebut dapat diposting melalui website yang sudah disediakan yaitu dengan alamat http://statistikapendidikan.com.

\section{B. Pembatasan Masalah}

Banyaknya permasalahan yang berkaitan pengembangan video tutorial pada mata kuliah pengantar statistika pendidikan, maka dalam penelitian ini dibatasi pada bagaimana mengembangkan video tutorial mata kuliah pengantar statistika pendidikan dengan menggunakan sebuah aplikasi pembuat video tutorial yaitu Camtasia Studio untuk pembelajaran e-learning di Jurusan Ilmu Sosial Politik Fakultas Ilmu Sosial Universitas Negeri Jakarta.

\section{Perumusan Masalah}

Berdasarkan latar belakang masalah tersebut di atas, maka dapatlah dirumuskan permasalahannya: "Bagaimana mengembangkan video tutorial dengan menggunakan aplikasi camtasia studio pada mata kuliah pengantar statistika pendidikan untuk pembelajaran e-learning mahasiswa di Jurusan Ilmu Sosial Politik Fakultas Ilmu Sosial Universitas Negeri Jakarta?".

\section{KAJIAN PUSTAKA}

\section{A. Video Tutorial Menggunakan} Aplikasi Camtasia Studio

Video tutorial merupakan panduan tentang cara menjelaskan sesuatu, baik materi pembelajaran atau pelatihan (training) maupun proses pengoperasian suatu sistem (hardware dan software) yang dikemas dalam bentuk video. Video tutorial adalah salah satu media pembelajaran yang berfungsi untuk melakukan pertukaran informasi antara pengirim (transmitter) dan penerima (receiver) sehingga tercapai suatu tujuan yang dikehendaki. (Aripin B.C, 2009: 1). Untuk membuat sebuah video tutorial salah satu aplikasi yang dapat digunakan adalah Camtasia Studio, yang merupakan perangkat lunak (software) yang dikembangkan oleh Techsmith Corporation khusus bidang multimedia. Camtasia Studio adalah program aplikasi yang dikemas untuk recording, editing, dan publishing dalam 
membuat video presentasi yang ada pada layar (screen) komputer

Camtasia Studio dapat membantu dan melatih seorang guru/dosen dalam menyampaikan serta berinteraksi dengan audiens, Camtasia Studio memiliki kemampuan untuk merekam sesuatu yang ada dalam layar, termasuk kegiatan di desktop, presentasi Powerpoint, narasi suara, dan webcam studio. Dengan menggunakan Camtasia Studio seorang guru dapat menyajikan video tutorial perkuliahannya baik dalam bentuk halaman web, CD-ROOM, maupun peralatan portable lainnya.

Aripin (2009: 3) menyebutkan alasan mengapa digunakannya Aplikasi Camtasia Studio, yaitu sebagai berikut:

1) Menjangkau siapapun dan dimanapun

2) Tidak perlu memiliki kemampuan multimedia

3) Full-motion Recording

4) Tidak membutuhkan server

5) Menyediakan fasilitas editing lebih lanjut

6) Tidak membatasi format file

7) Compatible dengan tools lainnya.

Aplikasi Camtasia Studio sebagai salah satu aplikasi yang dapat digunakan untuk membuat sebuah video tutorial, bekerja dengan tiga tahapan, yaitu recording, editing, dan publishing.
1) Recording, melalui Camtasia studio Recording, kita dapat merekam semua atau beberapa bagian pada layar (screen) seperti menekan mouse atau tombol keyboard, merekam presentasi powerpoint, seperti narasi, audio, slide transitions, animasi, merekam suara (audio) dari microfon dan aplikasi audio, menggambar dan highlight pada screen dengan menggunakan screenPad, merekam keterangan gambar dengan ScreenDraw, menggunakan hotkeys untuk memperkecil (zoom out) dan memperbesar (zoom in).

2) Editing, pada menu utama camtasia studio kita dapat mengimport video, audio, dan file gambar (image) ke dalam project. File dapat diimpor dengan sangat mudah dan sederhana dengan cara mengedrag dan drop file yang terletak dalam clip bin ke dalam timeline, kemudian edit sesuai dengan kebutuhan.

3) Publishing, dengan camtasia studio video tutorial yang sudah dihasilkan dapat dipublish melalui CD-ROM, Flash, Web, DVD, email, mempublish dengan file format Ipod video, macromedia flash, Apple Quick Time, Windows Media, RealMedia. Dengan kelebihan ini tentunya hasil video tutorial yang 
sudah dibuat dapat menjangkau ke semua orang yang membutuhkan khususnya mahasiswa.

\section{B. Pembelajaran E-Learning Berbasis Web}

\section{Pengertian E-Learning}

Istilah e-learning dapat ditemukan sebagai salah satu model pembelajaran berbasis e-learning sekaligus penggunaan media pembelajaran berbasis e-learning, $e$ learning sendiri merupakan singkatan dari electronic learning. Pembelajaran berbasis e-learning berarti proses pembelajaran menggunakan media elektronik khususnya internet sebagai sistem pembelajarannnya. Dengan E-Learning, memungkinkan pembelajar (dosen) atau peserta didik/mahasiswa untuk belajar melalui komputer tanpa terikat oleh tempat dan waktu dalam arti pembelajaran dapat dilakukan kapanpun dan dimanapun sepanjang terhubung dengan akses internet. Menurut Jaya Kumar C. Koran (2002), elearning diartikan sebagai sembarang pengajaran dan pembelajaran yang menggunakan rangkaian elektronik (LAN, WAN, atau internet) untuk menyampaikan isi pembelajaran, interaksi, atau bimbingan.

Sedangkan Dong (dalam Kamarga, 2002), mendefinisikan e-learning sebagai kegiatan belajar asynchronous melalui perangkat elektronik komputer yang memperoleh bahan belajar yang sesuai dengan kebutuhannya. Rosenberg (2001), menyebutkan bahwa e-learning merujuk pada penggunaan teknologi internet untuk mengirimkan serangkaian solusi yang dapat meningkatkan pengetahuan dan keterampilan. Dan Darin E. Hartley (Hartley, 2001), mendefinisikan e-learning merupakan suatu jenis belajar mengajar yang memungkinkan tersampaikannya bahan ajar ke siswa dengan menggunakan media Internet, Intranet atau media jaringan komputer lain.

\section{Website/situs}

Situs web adalah sebutan bagi sekelompok halaman web (web page), yang umumnya merupakan bagian dari suatu nama domain (domain name) atau sub domain di World Wide Web (WWW) di Internet. WWW terdiri dari seluruh situs web yang tersedia kepada publik. Halaman-halaman sebuah situs web diakses dari sebuah URL yang menjadi "akar" (root), yang disebut homepage (halaman induk; sering diterjemahkan menjadi "beranda", "halaman muka"), dan biasanya disimpan dalam server yang sama. Website atau situs dapat diartikan sebagai kumpulan halaman-halaman yang digunakan untuk menampilkan informasi teks, gambar diam atau gerak, animasi, suara, dan atau gabungan dari semuanya itu baik yang bersifat statis maupun 
$64 \quad$ JURNAL ILMIAH MIMBAR DEMOKRASI

dinamis yang membentuk satu rangkaian bangunan yang saling terkait dimana masing-masing dihubungkan dengan jaringan-jaringan halaman (hyperlink). Berikut adalah unsur-unsur yang terdapat terdapat dalam sebuah sistem website yaitu antara lain:

a. Nama domain (Domain name/URL Uniform Resource Locator)

Pengertian nama domain atau biasa disebut dengan Domain Name atau URL adalah alamat unik di dunia internet yang digunakan untuk mengidentifikasi sebuah website, atau dengan kata lain domain name adalah alamat yang digunakan untuk menemukan sebuah website pada dunia internet. Contohnya adalah http://www.unj.ac.id.,

http://www.ppknunj.org., atau http://skripsippknunj.com. Nama domain diperjualbelikan secara bebas di internet dengan status sewa tahunan. Nama domain sendiri mempunyai identifikasi ekstensi/akhiran sesuai dengan kepentingan dan lokasi keberadaan website tersebut. Contoh nama domain ber-ekstensi internasional adalah com, net, org, info, biz, name, ws. Contoh nama domain berekstensi lokasi negara Indonesia adalah co.id (untuk nama domain website perusahaan), ac.id (nama domain website pendidikan), go.id (nama domain website instansi pemerintah), or.id (nama domain website organisasi).

\section{b. Rumah tempat website (Web hosting)}

Pengertian Web Hosting dapat diartikan sebagai ruangan yang terdapat dalam harddisk tempat menyimpan berbagai data, file-file, gambar dan lain sebagainya yang akan ditampilkan di website. Web Hosting juga diperoleh dengan menyewa bulanan atau tahunan. Besarnya hosting ditentukan ruangan harddisk dengan ukuran MB (Mega Byte) atau GB (Giga Byte). Lama penyewaan web hosting rata-rata dihitung per tahun. Penyewaan hosting dilakukan dari perusahaan-perusahaan penyewa web hosting yang banyak dijumpai baik di Indonesia maupun Luar Negeri, dengan fasilitas yang berbeda-beda.

\section{c. Kekuatan atau kelebihan e-learning berbasis web}

Sebagian masyarakat dan beberapa kalangan dosen khususnya yang tidak memiliki latar belakang kemampuan teknologi informasi mengeluh betapa sulitnya membangun sebuah personal web, dengan berbagai persyaratan pemograman dan hosting yang memakan waktu dan energi. Dengan kemajuan teknologi yang memudahkan bagi penggunanya, maka setiap orang termasuk seorang dosen dapat bermigrasi ke pembelajaran e-learning berbasis web, sehingga ilmu yang dimiliki dapat dituangkan ke dalam cyber yang dapat dimanfaatkan oleh mahasiswanya 
dan tentunya demi kemajuan pendidikan bangsa Indonesia yang tercinta.

Muhammad Adri (2008:

menyebutkan ditemukan enam pilar kunci, sebagai kekuatan atau kelebihan e-learning berbasis web yaitu:

a. Publishable, yaitu dapat langsung memposting berita, dengan mudah, murah dan dapat dibaca dimanapun dan kapanpun.

b. Findable, yaitu mudah ditemukan lewat situs pencari berdasarkan subyek, nama penulis, atau keduanya. Semakin tambun suatu webaite, biasanya ia semakin digemari.

c. Social, yaitu bahwa percakapan di website yang menarik berdasarkan topik beralih dari suatu situs ke situs web, nge-link dari suatu link ke link lain. Melalui website, mereka yang memiliki minat yang sama dapat membangun network, berdiskusi, lintas geografi.

d. Viral, yaitu bahwa dengan website, informasi menyebar lebih cepat dibanding new service.

e. Syndicatable, bahwa Content yang kaya mudah disindikasikan oleh siapa saja. Dunia yang penuh dengan ribuan informasi yang positif di dalam internet atau web dapat diperoleh dengan mudah. f. Linkable, yaitu bahwa setiap website dapat nge-link ke yang lain, memiliki akses kepuluhan juta orang yang mengunjungi website setiap hari yang bercirikan komunikasi internet dua arah.

\section{METODOLOGI PENELITIAN}

\section{A. Tujuan Penelitian}

Tujuan penelitian ini adalah menghasilkan video tutorial mata kuliah Pengantar Statistika Pendidikan dengan bantuan aplikasi Camtasia Studio untuk perkuliahan e-learning di Jurusan Ilmu Sosial Politik Fakultas Ilmu Sosial Universitas Negeri Jakarta.

\section{B. Tempat dan Waktu Penelitian}

Penelitian ini dilakukan pada mahasiswa peserta mata kuliah pengantar statistika pendidikan di Jurusan Ilmu Sosial Politik Fakultas Ilmu Sosial Universitas Negeri Jakarta. Sedangkan waktu penelitian dilaksanakan pada bulan Maret-Agustus 2014.

\section{Metode Penelitian}

Pendekatan penelitian yang digunakan peneliti untuk menjawab pertanyaan penelitian yaitu dengan menggunakan penelitian Research and Development yaitu dengan mengembangkan video tutorial pada mata kuliah pengantar statistika pendidikan 
untuk pembelajaran e-learning di Jurusan Ilmu Sosial Politik Fakultas Ilmu Sosial Universitas Negeri Jakarta.

\section{Teknik Pengumpulan Data}

Teknik pengumpulan data yang dilaksanakan penelitian yaitu antara lain dengan menggunakan teknik survei. Sedangkan untuk membuat video tutorial mata kuliah pengantar statistika pendidikan untuk pembelajaran e-learning dilakukan dengan beberapa langkah, diantaranya :

1. Membuat naskah video tutorial sesuai dengan Silabus dan Satuan Acara Perkuliahan

2. Melakukan Proses Recording atau proses perekaman melalui aplikasi Camtasia Studio

3. Melakukan proses editing video tutorial hasil recording

4. Melakukan uji coba sistem agar sistem dapat berjalan sesuai dengan tujuan yang diharapkan

5. Analisis terhadap kelayakan video tutorial yang dihasilkan

6. Memproduksi atau mempublishing video tutorial pada website http://statistikapendidikan.com

\section{E. Teknik Analisis Data}

Analisis data dilakukan terhadap video tutorial mata kuliah pengantar statistika pendidikan yang dihasilkan untuk mengetahui unjuk kerja dan kelayakannya untuk digunakan sebagai model dan media pembelajaran e-learning pada mahasiswa Jurusan Ilmu Sosial Politik Fakultas Ilmu Sosial Universitas Negeri Jakarta, yang diposting melalui website http://statistikapendidikan.com

\section{HASIL PENELITIAN DAN PENGEMBANGAN}

\section{A. Hasil Penelitian}

Penelitian ini merupakan penelitian pengembangan ( $R$ \& D) yang bertujuan tersedianya video tutorial mata kuliah Pengantar Statistika Pendidikan untuk pembelajaran e-learning sehingga pada akhirnya kualitas pembelajaran dan hasil belajar mahasiswa pada mata kuliah pengantar statistika pendidikan di Jurusan Ilmu Sosial Politik Fakultas Ilmu Sosial Universitas Negeri Jakarta dapat meningkat dengan baik. Penelitian pengembangan ini dilakukan dengan tahapan atau langkah-langkah sebagai berikut:

\section{1) Need Analysis}

Berdasarkan permasalahan antara lain hasil belajar mata kuliah Pengantar Statistika Pendidikan yang belum cukup memuaskan, jumlah SKS yang sangat terbatas hanya 2 SKS, keterbatasan waktu pembelajaran yang tersedia dalam proses pembelajaran di dalam kelas yang hanya 100 menit setiap pertemuan dengan materi 
pembelajaran Pengantar Statistika Pendidikan yang cukup banyak yang harus dipelajari mahasiswa, materi Pengantar Statistika Pendidikan yang dinilai oleh sebagian mahasiswa materinya cukup sulit bagi mahasiswa ilmu sosial khususnya mahasiswa Program Studi S1 PPKN FIS UNJ, dan perkembangan Teknologi Informasi yang cukup berkembang dewasa ini, maka dianalisis perlunya kebutuhan video tutorial pada mata kuliah pengantar statistika pendidikan untuk pembelajaran e-learning.

Dengan video tutorial pada mata kuliah Pengantar Statistika Pendidikan memungkinkan mahasiswa untuk mengulang pembelajaran mata kuliah Pengantar Statistika Pendidikan, terlebih dengan diuploadnya video tutorial tersebut dalam sebuah website maka mahasiswa dapat belajar tanpa terikat oleh tempat dan waktu, pembelajaran dapat dilakukan kapanpun dan dimanapun sepanjang terhubung dengan akses internet. Pada tahap ini dianalisis aplikasi yang dapat digunakan untuk membuat video tutorial pengantar statistika pendidikan dengan menggunakan program SPSS yang dianggap sesuai dengan kebutuhan mahasiswa dan dosen yaitu dengan menggunakan aplikasi pembuat video tutorial yang bernama Camtasia Studio, selanjutnya untuk pembelajaran e-learningnya dianalisis kebutuhan
Hosting/server untuk menyimpan data online dan domain/nama website untuk elearning, selanjutnya dianalisis tujuan dari materi pembelajaran Pengantar Statistika Pendidikan, Silabus/Satuan Acara Perkuliahan, analisis materi pembelajaran Pengantar Statistika Pendidikan (materi pembelajaran statistika deskriptif maupun statistik inferensial).

\section{2) Pengembangan Produk Awal/Desain}

Berdasarkan analisis permasalahan di atas, selanjutnya analisis tentang bentuk video tutorial pengantar statistika pendidikan dengan program SPSS yang akan dibuat dengan menggunakan aplikasi pembuat video tutorial bernama camtasia studio, sebelumnya disiapkan modul atau materi pengantar statistika pendidikan yang akan digunakan untuk dibuatkan video tutorialnya. Berikutnya untuk pembelajaran e-learningnya maka dirancan/didesain bentuk website dengan menggunakan CMS Wordpress, pilihan sewa hosting atau server tempat dokumen atau file dapat disimpan secara online dalam hal ini menggunakan jasa sewa hosting atau server dari Hostgator.com yang merupakan jasa penyedia hosting yang cukup terkenal di Amerika Serikat, kemudian dirancang nama domain atau nama website yang dipandang mewakili website e-learning pada mata kuliah pengantar statistika pendidikan dengan 
menggunakan jasa sewa domain atau nama website dari namecheap.com yang juga merupakan perusahaan penyedia jasa sewa domain yang cukup terkenal di dunia. Adapun nama website yang digunakan untuk website e-learning pada mata kuliah pengantar statistika pendidikan di Program Studi S1 PPKN FIS UNJ adalah http://statistikapendidikan.com. Langkah berikutnya setelah dirancang CMS yang akan digunakan, tempat sewa hosting dan domain, adalah merancang bentuk websitenya termasuk bagaimana tampilannya yang menarik, menu-menu yang harus disediakan dalam website khususnya adalah menu video tutorial dengan menggunakan aplikasi SPSS yang dapat didownload oleh mahasiswa atau dapat dilihat tampilan videonya melalui website yang tersedia. Berikut tampilan website http://statistikapendidikan.com.

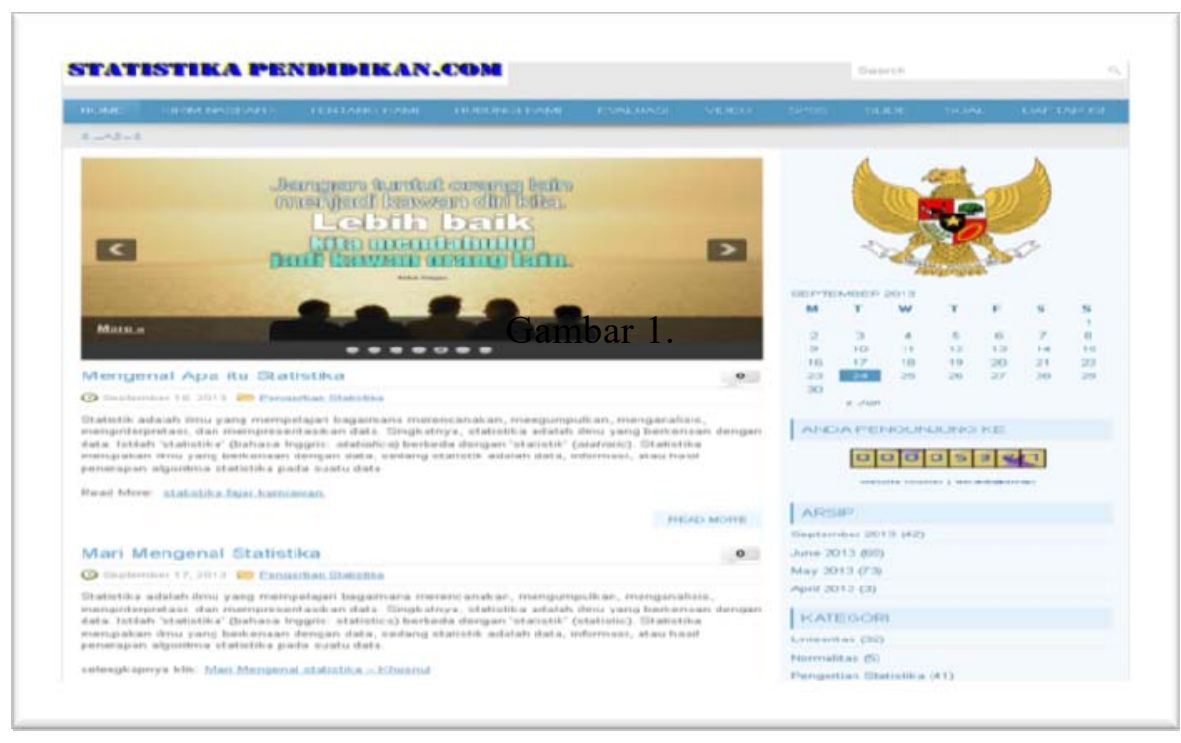

Gambar. 1

Tampilan halaman website http://statistikapendidikan.com 


\section{3) Validasi Ahli}

Agar video tutorial pengantar statistika pendidikan dan website e-learning berjalan sesuai dengan fungsinya terlebih dahulu berkonsultasi kepada ahli dalam bidang Teknologi Informasi/IT, dalam hal ini validitasi dilakukan oleh dosen Fakultas Teknik Universitas Negeri Jakarta yang cukup kompeten dalam bidang IT, hal ini dimaksudkan agar video tutorial dan website tersebut tidak menimbulkan masalah seperti tidak berfungsinya atau errornya video tutorial atau website pada saat dioperasikan baik oleh mahasiswa maupun oleh dosen pengampu mata kuliah, dan juga untuk menghindari adanya gangguan dari pihak yang tidak bertanggung jawab atau hacker sehingga website tidak berjalan sebagaimana fungsinya.

\section{4) Uji Coba Lapangan}

Berdasarkan desain atau rancangan yang disusun, selanjutnya desain tersebut diimplementasikan melalui pembuatan sebuah video tutorial pengantar statistika pendidikan dan website e-learning. Adapun nama website yang dikembangkan pada mata kuliah Pengantar Statistika Pendidikan PKn di Program Studi S1 PPKN FIS UNJ yaitu http://statistikapendidikan.com sebagaimana ditunjukkan pada tampilan gambar berikut ini.

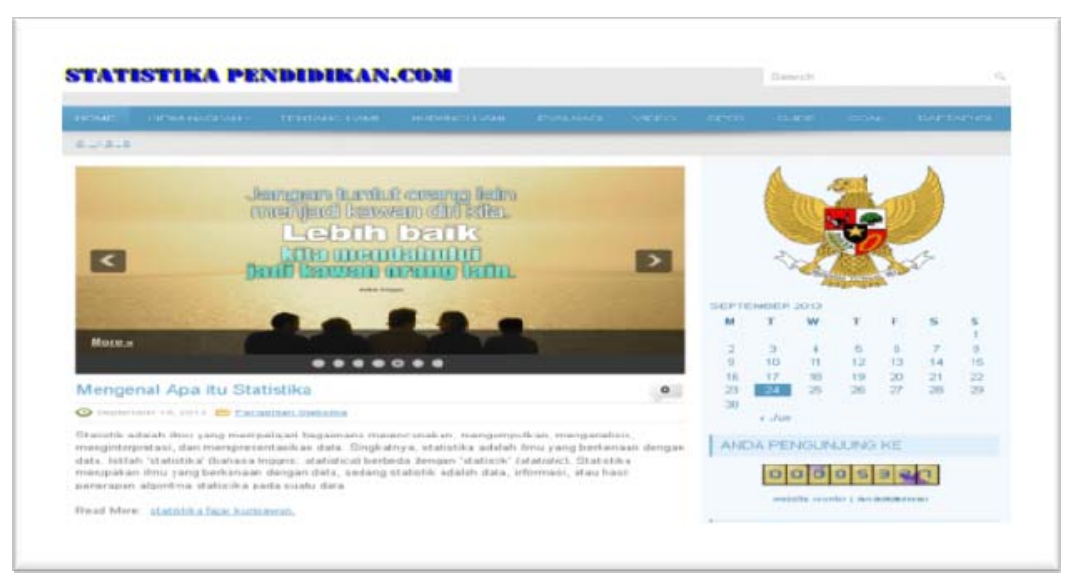

Gambar 2.

Tampilan website http://statistikapendidikan.com 
Tampilan yang ditunjukkan dalam website http://statistikapendidikan.com terdapat beberapa menu yaitu antara lain menu Home, Kirim Naskah, Tentang Kami, Hubungi Kami, Slide, Soal, Daftar Isi, Silabus dan video tutorial mata kuliah Pengantar Statistika Pendidikan.

\section{STaTISTIKa PENDIDIKaN.COM}

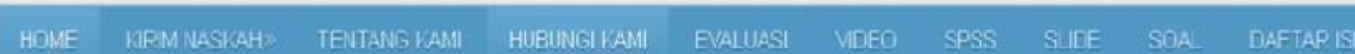

Gambar 3

Tampilan Menu Website http://statistikapendidikan.com

Salah satu menu yang ada adalah menu video tutorial. Melalui menu video pada website ini disediakan beberapa video tutorial yang dapat digunakan oleh mahasiswa untuk mempelajari tentang statistika pendidikan, video tutorial ini berisi tutorial tentang pemanfaatan aplikasi SPSS sebagai aplikasi pengolah data yang cukup popular, yang memudahkan mahasiswa atau calon peneliti dalam mengolah data yang sudah diperolehnya. Dengan tersedianya video tutorial maka mahasiswa akan lebih mudah dalam mempelajari tentang statistika pendidikan, dan dapat mengulang kembali tayangan video tersebut jika dirasa ada materi yang belum dipahami. Sehingga ke depan semua materi pembelajaran pengantar statistika selama 14 kali pertemuan dapat dibuatkan video tutorialnya, seperti mahasiswa sedang menyaksikan dosen mata kuliah sedang memberikan kuliah di kelas. Saat ini materi pembelajaran Pengantar Statistika Pendidikan belum seluruhnya dibuatkan video tutorialnya, dan beberapa video diambil dari beberapa sumber lain yang relevan dengan pembelajaran. Belum sepenuhnya materi dapat dibuatkan video tutorial karena beberapa kendala antara lain untuk membuat sebuah video tutorial membutuhkan cukup waktu, biaya dan tenaga. Berikut video tutorial yang tersedia dalam website http://statistikapendidikan.com yaitu antara lain uji normalitas, uji korelasi parsial, uji non parametric, uji regresi ganda, uji validitas, uji relaibilitas, uji t sampel berhubungan, dan uji t sampel bebas (tak berhubungan), ke depan video tutorial pengantar statistika pendidikan dapat dibuatkan menjadi lebih lengkap dan komprehensip sehingga mahasiswa dapat 
mengulang pembelajaran jika dirasa pembelajaran yang diberikan di kelas oleh diharapkan kualitas pembelajaran menjadi dosen pengampu belum memadai, sehingga lebih baik.

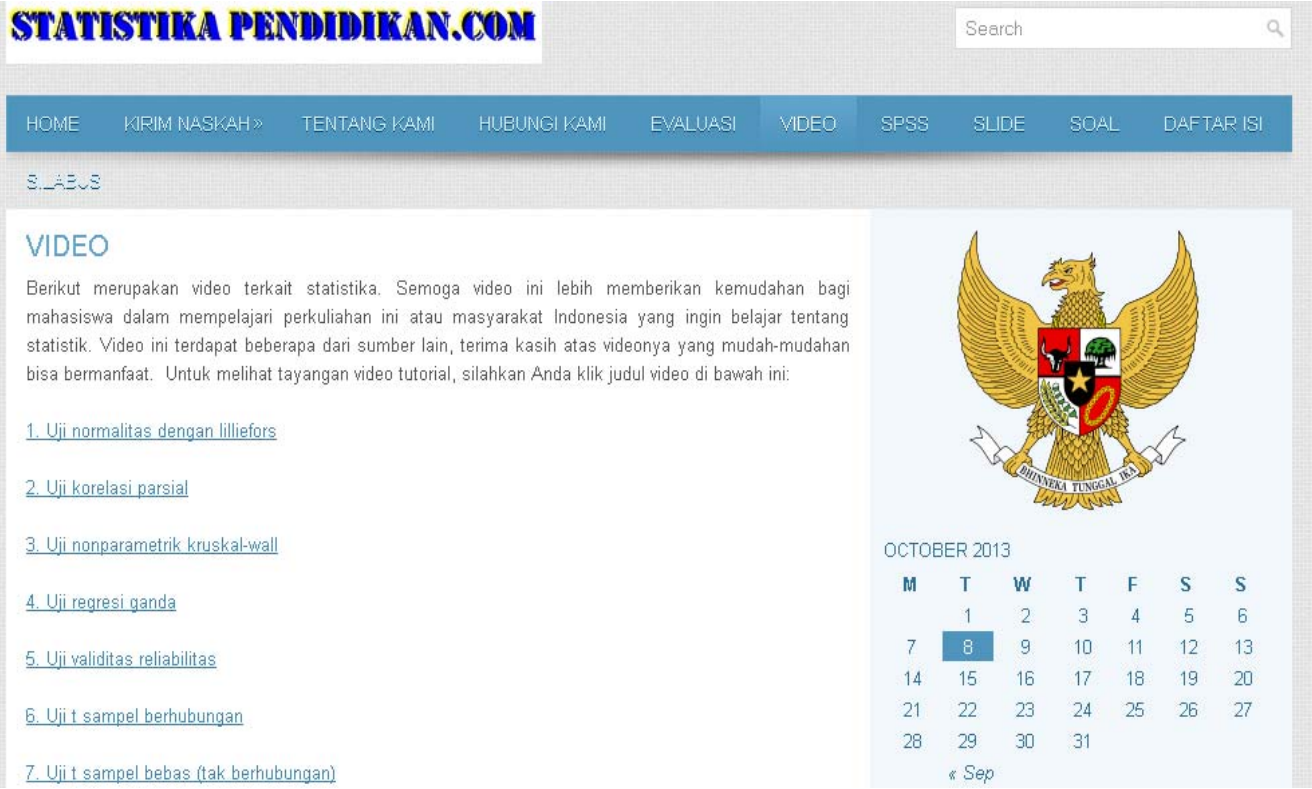

Gambar 3.

Video yang ditampilkan dalam website http://statistikapendidikan.com yang dapat dilihat atau didownload oleh mahasiswa atau pengunjung web.

\section{Hasil Uji Kualitas/Kelayakan}

\begin{tabular}{|c|c|c|c|c|c|c|c|c|c|c|c|c|c|c|c|}
\hline \multirow{2}{*}{ No. } & \multirow{2}{*}{ Keterangan } & \multicolumn{12}{|c|}{ Jawaban Responden } & \multirow{2}{*}{$\begin{array}{c}\text { Jumlah } \\
\text { Nilai }\end{array}$} & \multirow{2}{*}{$\begin{array}{c}\text { Rata2 } \\
\text { Nilai }\end{array}$} \\
\hline & & 1 & $\%$ & 2 & $\%$ & 3 & $\%$ & 4 & $\%$ & 5 & $\%$ & Jml. & $\%$ & & \\
\hline 1 & $\begin{array}{l}\text { Video tutorial pengantar } \\
\text { statistika pendidikan } \\
\text { mudah dioperasikan }\end{array}$ & 3 & $9 \%$ & 4 & $11 \%$ & 8 & $23 \%$ & 20 & $57 \%$ & 2 & $6 \%$ & 37 & $100 \%$ & 125 & 3.38 \\
\hline 2 & $\begin{array}{l}\text { Video tutorial dalam } \\
\text { web e-learning statistika } \\
\text { pendidikan sudah baik }\end{array}$ & 1 & $3 \%$ & 3 & $9 \%$ & 11 & $31 \%$ & 18 & $51 \%$ & 4 & $11 \%$ & 37 & $100 \%$ & 132 & 3.57 \\
\hline 3 & $\begin{array}{|llr|}\text { Video } & \text { Tutorial } & \text { sudah } \\
\text { sesuai } & \text { dengan } & \text { tujuan } \\
\text { pembelajaran yang } & \text { ingin } \\
\text { dicapai } & \end{array}$ & 1 & $3 \%$ & 1 & $3 \%$ & 9 & $26 \%$ & 17 & $49 \%$ & 9 & $26 \%$ & 37 & $100 \%$ & 143 & 3.86 \\
\hline 4 & $\begin{array}{|lr|}\text { Video } & \text { tutorial dalam } \\
\text { web r r e-learning } \\
\text { membantu memudahkan } \\
\text { pemahaman tentang } \\
\text { statistika pendidikan }\end{array}$ & & $0 \%$ & 2 & $6 \%$ & 8 & $23 \%$ & 22 & $63 \%$ & 5 & $14 \%$ & 37 & $100 \%$ & 141 & 3.81 \\
\hline 5 & $\begin{array}{|lr|}\text { Video } & \text { Tutorial } \\
\text { disajikan } & \text { yang } \\
\text { statistika } & \text { pendidikan } \\
\text { dapat } & \\
\text { didownload/disimpan } \\
\text { kedalam } & \\
\end{array}$ & & $0 \%$ & 1 & $3 \%$ & 3 & $9 \%$ & 19 & $54 \%$ & 14 & $40 \%$ & 37 & $100 \%$ & 157 & 4.24 \\
\hline
\end{tabular}




\begin{tabular}{|c|c|c|c|c|c|c|c|c|c|c|c|c|c|c|c|}
\hline & komputer/flashdisk & & & & & & & & & & & & & & \\
\hline 6 & $\begin{array}{lr}\text { Dengan } & \text { video tutorial } \\
\text { dengan } & \text { e-learning } \\
\text { statistika } & \text { pendidikan } \\
\text { belajar dapat dilakukan } \\
\text { kapan dan dimanapun }\end{array}$ & & $0 \%$ & 0 & $0 \%$ & 2 & $6 \%$ & 22 & $63 \%$ & 13 & $37 \%$ & 37 & $100 \%$ & 159 & 4.30 \\
\hline 7 & 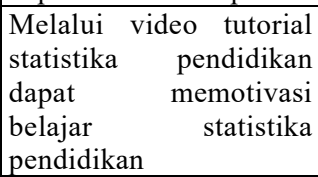 & & $0 \%$ & 1 & $3 \%$ & 4 & $11 \%$ & 21 & $60 \%$ & 11 & $31 \%$ & 37 & $100 \%$ & 153 & 4.14 \\
\hline 8 & $\begin{array}{l}\text { Dengan video tutorial } \\
\text { statistika pendidikan } \\
\text { membantu memudahkan } \\
\text { pemahaman tentang } \\
\text { statistika pendidikan }\end{array}$ & & $0 \%$ & & $0 \%$ & 5 & $14 \%$ & 24 & $69 \%$ & 8 & $23 \%$ & 37 & $100 \%$ & 151 & 4.08 \\
\hline 9 & \begin{tabular}{|lr} 
Video tutorial & statistika \\
pendidikan & mudah \\
dijalankan & langsung \\
lewat website & statistika \\
pendidikan & \\
\end{tabular} & 6 & $17 \%$ & 7 & $20 \%$ & 17 & $49 \%$ & 7 & $20 \%$ & 0 & $0 \%$ & 37 & $100 \%$ & 99 & 2.68 \\
\hline 10 & $\begin{array}{l}\text { Website } \\
\text { pendidikan dapat dibuka } \\
\text { pada mesin } \\
\text { (google dan } \\
\text { dengan baik }\end{array}$ & & $0 \%$ & & $0 \%$ & 5 & $14 \%$ & 22 & $63 \%$ & 10 & $29 \%$ & 37 & $100 \%$ & 153 & 4.14 \\
\hline \multirow{2}{*}{ No. } & \multirow{2}{*}{ Keterangan } & \multicolumn{12}{|c|}{ Jawaban Responden } & \multirow{2}{*}{$\underset{\text { Numlah }}{\text { Nilai }}$} & \multirow{2}{*}{$\begin{array}{r}\text { Rata2 } \\
\text { Nilai }\end{array}$} \\
\hline & & 1 & $\%$ & 2 & $\%$ & 3 & $\%$ & 4 & $\%$ & 5 & $\%$ & Jml. & $\%$ & & \\
\hline 11 & $\begin{array}{l}\text { Materi dalam video } \\
\text { tutorial sudah sesuai dan } \\
\text { lengkap }\end{array}$ & 2 & $6 \%$ & 2 & $6 \%$ & 12 & $34 \%$ & 19 & $54 \%$ & 2 & $6 \%$ & 37 & $100 \%$ & 128 & 3.46 \\
\hline 12 & $\begin{array}{l}\text { Video tutorial memiliki } \\
\text { tingkat } \\
\text { reliabilitas/kehandalan, } \\
\text { tidak mudah hang/error }\end{array}$ & & $0 \%$ & 1 & $3 \%$ & 4 & $11 \%$ & 24 & $69 \%$ & 8 & $23 \%$ & 37 & $100 \%$ & 150 & 4.05 \\
\hline 13 & \begin{tabular}{|lr} 
Kecepatan & membuka \\
halaman web & statistika \\
pendidikan & berjalan \\
dengan baik & \\
\end{tabular} & & $0 \%$ & & $0 \%$ & 6 & $17 \%$ & 24 & $69 \%$ & 5 & $14 \%$ & 35 & $95 \%$ & 139 & 3.76 \\
\hline 14 & $\begin{array}{l}\text { Website } r \text { statistika } \\
\text { pendidikan menyajikan } \\
\text { materi pembelajaran } \\
\text { yang terkini (up to date) } \\
\text { sesuairan } \\
\text { perkembangan }\end{array}$ & 1 & $3 \%$ & 1 & $3 \%$ & 4 & $11 \%$ & 23 & $66 \%$ & 8 & $23 \%$ & 37 & $100 \%$ & 147 & 3.97 \\
\hline 15 & $\begin{array}{lr}\text { Penggunaan } & \text { bahasa } \\
\text { dalam website } & \text { statistika } \\
\text { pendidikan } & \text { sudah } \\
\text { sesuai, } & \text { mudah } \\
\text { dimengerti } & \end{array}$ & & $0 \%$ & & $0 \%$ & 3 & $9 \%$ & 26 & $74 \%$ & 8 & $23 \%$ & 37 & $100 \%$ & 153 & 4.14 \\
\hline 14 & $\begin{array}{lr}\text { Website } & \text { statistika } \\
\text { pendidikan } & \text { mudah } \\
\text { dioperasikan } & \\
\end{array}$ & & $0 \%$ & & $0 \%$ & 1 & $3 \%$ & 22 & $63 \%$ & 14 & $40 \%$ & 37 & $100 \%$ & 161 & 4.35 \\
\hline 17 & \begin{tabular}{|lr} 
Website & statistika \\
pendidikan & memiliki \\
tingkat & reliabilitas \\
/kehandalan, & tidak \\
mudah hang/error & \\
\end{tabular} & & $0 \%$ & & $0 \%$ & 7 & $20 \%$ & 27 & $77 \%$ & 3 & $9 \%$ & 37 & $100 \%$ & 144 & 3.89 \\
\hline 18 & $\begin{array}{l}\text { Melalui } \quad \text { website } \\
\text { statistika pendidikan } \\
\text { pembelajaran jadi lebih } \\
\text { efektif dan efesien }\end{array}$ & & $0 \%$ & & $0 \%$ & 4 & $11 \%$ & 22 & $63 \%$ & 11 & $31 \%$ & 37 & $100 \%$ & 155 & 4.19 \\
\hline
\end{tabular}




\begin{tabular}{|l|l|l|l|l|l|l|l|l|l|l|l|l|l|l|l|}
19 & $\begin{array}{l}\text { Tampilan } \\
\text { statistikar pendidikan } \\
\text { secara umum menarik }\end{array}$
\end{tabular}

Tabel 1. Hasil Uji Kualitas/Kelayakan Video Tutorial untuk pembelajaran e-learning

Analisis deskriptif terhadap kelayakan video tutorial Pengantar Statistika Pendidikan untuk pembelajaran e-learning pada mata kuliah Pengantar Statistika Pendidikan di Program Studi S1 PPKN FIS UNJ, sebagaimana dikemukakan Sambas Ali Muhidin dan Maman Abdurahman (2007: 146) maka dapat digunakan tabel sebagai berikut:

\begin{tabular}{|c|c|l|}
\hline No. & Rentang Kategori Skor & \multicolumn{1}{|c|}{ Penafsiran } \\
\hline 1. & $1,00-1,99$ & $\begin{array}{l}\text { Sangat Tidak } \\
\text { Baik }\end{array}$ \\
\hline 2. & $1,80-2,59$ & Tidak Baik \\
\hline 3. & $2,60-3,39$ & Cukup Baik \\
\hline 4. & $3,40-4,19$ & Baik \\
\hline 5. & $4,20-5,00$ & Sangat Baik \\
\hline
\end{tabular}

Tabel 2. Rentang kategori skor menurut Sambas A.M.

Berdasarkan hasil uji

kelayakan/kualitas video tutorial Pengantar Statistika Pendidikan untuk pembelajaran e-learning yaitu melalui website http://statistikapendidikan.com diperoleh gambaran secara umum bahwa video tutorial pengantar statistika pendidikan diperoleh angka rata-rata 3,89 yaitu berada padarentangan kategori 3,40 - 4,19 dengan kategori dikatakan BAIK. Nilai terendah diperoleh pada item pertanyaan apakah video tutorial statistika pendidikan mudah dijalankan langsung lewat website statistika pendidikan pada item ini dikarenakan video memiliki kapasitas yang cukup besar sehingga seringkali kalau tidak didukung dengan fasilitas internet yang baik biasanya video tidak berjalan dengan baik atau berjalan lambat, sehingga kurang efektif jika dilihat langsung melalui 
situs

atau

website

http://statistikapendidikan.com, dan ada sekitar 34\% responden yang menyatakan bahwa materi video tutorial yang tersedia dalam website belum lengkap, hal ini karena memang belum semua video diupload/diunggah dalam website dengan berbagai pertimbangan antara lain karena kapasitas yang cukup besar sehingga cukup kesulitan untuk upload kedalam website dan beberapa keterbatasan lainnya yang menyebabkan belum semua video tutorial ditampilkan dari pembelajaran Pengantar Statistika Pendidikan. Dan ini tentu menjadi tantangan ke depan bagi peneliti khususnya dan dosen pengampu mata kuliah Pengantar Statistika Pendidikan bahwa diharapkan nantinya dalam website ini akan tersedia video tutorial selama 14 kali pertemuan perkuliahan, sehingga dengan adanya video tutorial seorang mahasiswa dapat melihat dan mendengarkan kembali penjelasan dan langkah-langkah dalam pembelajaran Pengantar Statistika Pendidikan selama 14 kali pertemuan perkuliahan, sehingga dosen tidak perlu mengulang-ulang materi, tetapi mahasiswa dapat melakukan penggulangan melalui video tutorial tersebut.

\section{B. Pembahasan}

Aplikasi Camtasia Studio merupakan salah satu aplikasi pembuat video tutorial yang cukup baik dan mudah dioperasikan oleh orang yang awam dalam kemampuan IT. Camtasia Studio dapat digunakan secara gratis dengan segala keterbatasannya, dan untuk mendapatkan aplikasi yang powerfull sebagai aplikasi pembuat video tutorial memang disediakan aplikasi berbayarnya. Dengan aplikasi camtasia studio dapat dihasilkan sebuah video tutorial yang dapat digunakan untuk pembelajaran yang dapat dikemas kedalam sebuah CD atau DVD yang dapat diputar oleh mahasiswa untuk mempelajari materi yang dianggap belum dikuasainya. Dan ini tentunya akan menghemat waktu dan biaya.

Untuk pembelajaran e-learningnya, dibutuhkan sebuah website yang dapat digunakan oleh mahasiswa atau orang lain yang berminat untuk dapat mendownload atau melihat atau belajar melalui website tersebut. Content Management System (CMS) Wordpress merupakan salah satu aplikasi pembuat sebuah website yang bersifat open source, yang tersedia gratis dan mudah digunakan baik oleh mahasiswa maupun dosen yang tidak berlatar belakang kemampuan IT sekalipun sehingga tidak harus mempelajari begitu dalam beberapa bahasa pemograman website yang membutuhkan waktu yang sangat lama, 
seperti HTML, PHP, MySQL dan lain-lain. Pembuatan website http://statistikapendidikan.com dengan menggunakan CMS Wordpress memiliki kelebihan dibandingkan dengan yang lainnya, salah satunya adalah cara mengolah wordpress sangat mudah dan tidak membuat orang yang awan dengan bahasa pemprograman merasa kesulitan.

Dengan tersedianya web http://statistikapendidikan.com untuk mata kuliah pengantar statistika pendidikan, memungkinkan mahasiswa membaca, mendownload, mengumpulkan tugas-tugas, berdiskusi, dan melihat video tutorial pembelajaran statistika pendidikan yang biasanya cukup rumit dan tidak tersedia cukup waktu kalau dilakukan di kelas, kini pembelajaran dapat dilakukan kapanpun dan dimanapun tanpa terikat waktu dan tempat asal terhubung akses internet. Hal ini tentu akan memudahkan mahasiswa dalam memahami materi pembelajaran statistik yang dianggap sebagai mata kuliah yang cukup sulit, sehingga pada akhirnya dapat meningkatkan mutu dan hasil belajar mahasiswa pada mata kuliah Pengantar Statistika Pendidikan.

Melalui

website http://statistikapendidikan.com mahasiswa dapat terlebih dahulu membaca, mendownload atau mencetak sebuah file, tulisan, artikel serta melihat video tutorialnya terlebih dahulu untuk dipelajari, sebelum mahasiswa kuliah tatap muka di kelas dengan dosen pengampu mata kuliah, atau sebaliknya materi yang dianggap masih belum dipahami di kelas maka seorang mahasiswa dapat memutar kembali tampilan video tutorialnya sehingga diharapkan membantu mahasiswa dalam memahami materi pembelajaran pengantar statistika pendidikan. hal ini tentu akan memudahkan mahasiswa dalam mengikuti perkuliahan. Seorang dosen juga tidak lagi harus mengulang-ulang pokok bahasan di depan kelas sehingga dari segi waktu dan tenaga lebih efesien dan hemat, mahasiswa yang kesulitan dapat memutar sendiri tampilan video tutorialnya dimanapun dan kapanpun, dan mahasiswa yang sudah menguasai pun menjadi tidak merasa bosan karena adanya pengulanganpengulangan materi di depan kelas.

Video tutorial yang tersedia dalam website http://statistikapendidikan.com atau dalam sebuah CD/DVD dapat didownload/diunduh serta dapat digandakan oleh mahasiswa, sehingga kapanpun dan dimanapun mahasiswa atau masyarakat membutuhkan materi terkait statistika pendidikan dengan menggunakan aplikasi SPSS khususnya dapat dipelajari dengan lebih mudah karena dapat dipelajari melalui sebuah video tutorial yang bersisi langkah-langkah bagaimana menerapkan aplikasi SPSS untuk mata kuliah statistika pendidikan. Sehingga mata 
kuliah Pengantar Statistik tidak lagi dianggap sebagai mata kuliah sulit/sukar oleh mahasiswa ilmu sosial khususnya mahasiswa pada program studi S1 PPKN Jurusan Ilmu Sosial Politik FIS UNJ.

\section{KESIMPULAN}

Berdasarkan hasil pengujian dan pembahasan yang telah dilakukan dapat ditarik kesimpulan sebagai berikut :

1. Video tutorial pengantar statistika pendidikan dengan aplikasi SPSS dan dengan e-learning berbasis web pada mata kuliah Pengantar Statistika Pendidikan di Jurusan Ilmu Sosial Politik FIS UNJ pada akhirnya dapat meningkatkan hasil belajar mahasiswa, dan memberikan sebuah terobosan baru dibidang pembelajaran pengantar statistika pendidikan.

2. Sistem e-Learning pada pembelajaran Pengantar Statistika Pendidikan adalah penting diperlukan untuk mengantisipasi perkembangan jaman dengan dukungan Teknologi Informasi dimana semua menuju ke era digital, baik mekanisme/model maupun konten.

3. Mahasiswa dapat mengulang pembelajaran pengantar statistika pendidikan melalui video tutorial yang dapat dilihat dan didownload melalui website http://statistikapendidikan.com kapanpun dan dimanapun tanpa terikat oleh waktu dan tempat.
4. Sistem pembelajaran e-learning dan menggunakan video tutorial pada mata kuliah Pengantar Statistika Pendidikan, dapat mengatasi keterbatasan waktu pembelajaran di kelas yang terbatas.

5. Pengembangan video tutorial dan model pembelajaran e-learning seperti pada mata Pengantar Statistika Pendidikan memerlukan keterlibatan berbagai pakar, terutama pakar pendidikan disatu pihak dan pakar teknologi informasi dipihak lain, sehingga tercipta perpaduan dan penciptaan inovasi pembelajaran yang lebih simple dan fleksibel.

\section{DAFTAR PUSTAKA}

Aripon B.C. Step by Step Membuat Video Tutorial Menggunakan Camtasia Studio. Bandung: Penerbit OASE MEDIA, 2009.

Adri, Muhmmad. Guru Go Blog: Optimalisasi Blog Untuk Pembelajaran. Jakarta: PT. Elex Media Komputindo, 2008.

Anwar, Oos M.Internet : Peluang dan Tantangan Pendidikan Nasional, Jakarta: Jurnal Teknodik Depdiknas, 2000.

Bloom, S. Benyamin . Taxonomy of Educational Objective The Classification of Educational Goal 2006. 
Gora S, Winastwan. Membuat CD Multimedia Interaktif untuk Bahan Ajar E-Learning. Jakarta: PT. Elex Media Koputindo, 2005.

Hamalik,

Oemar.

Media

Pendidikan.Bandung : Penerbit Alumni, 2001

Hasbullah. Implementasi E-Learning Dalam Pengembangan Pembelajaran di Perguruan Tinggi (Proceeding), Yogyakarta: SNPTE UNY, 2006.

Koran, Jaya Kumar C. Aplikasi E-Learning dalam Pengajaran dan pembelajaran di Sekolah Malaysia. (8 November 2002).

Masruri, M. Hilmi. Toko Online Canggih dengan Wordpress. Jakarta: PT. Elex Media Komputindo, 2012.

Raharjo. E-Learning Pengantar Statistika Pendidikan Berbasis Web Untuk Meningkatkan Hasil Belajar Mahasiswa PPKN FIS UNJ ( Hasil Penelitian). Jakarta: Fakultas Ilmu Sosial UNJ, 2013.
Romi Satria Wahono. Strategi Baru Pengelolaan Situs e-learning Gratis,http://www.ilmukomputer.co m, 2007.

Soekartawi. Prinsip Dasar E-Learning: Teori Dan Aplikasinya Di Indonesia, Jurnal Teknodik, Edisi No.12/VII/Oktober/2003.

Soekarwati.Prospek Pembelajaran Melalui Internet, Makalah Seminar Teknologi Kependidikan, Jakarta: UT Pustekkom dan IPTPI, 2002

Sukarto \& Hianoto S., Sukses Berbisnis di Internet Dalam 29 Hari. Jakarta: PT. Gramedia Pustaka Utama, 2009.

Turino, dkk. E-learning Bahasa Inggris Berbasis We. Semarang: Jurnal Teknologi Informasi, Volume 5 Nomor 2, Oktober 2009.

Widiyanto, Rahmad. Mudah Membangun Website Formal Secara Pro dengan Joomla. Jakarta: PT. Elex Media Komputindo, 2011. 
$78 \quad \mid \begin{aligned} & \text { JURNAL ILMIAH MIMBAR DEMOKRASI } \\ & \text { VOLUME 14, NOMOR 1, OKTOBER } 2014\end{aligned}$ 